\title{
Social environment as a cause of litter loss in laboratory mouse: a behavioural study
}

\section{Sophie Brajon ${ }^{1,2}$, Gabriela Munhoz Morello', Marta Sofia Teixeira' $^{1}$, Jan Hultgren ${ }^{3}$, Colin Gilbert ${ }^{2}$, I. Anna S. Olsson ${ }^{1}$}

\author{
1 Laboratory Animal Science, IBMC - Institute for Molecular and Cell Biology, and i3S - Institute for Research and \\ Innovation in Health, University of Porto, Rua Alfredo Allen, 4200-135, Porto, Portugal \\ 2 Babraham Institute, Babraham, Cambridge, CB22 3AT, United Kingdom \\ 3 Department of Animal Environment and Health, Swedish University of Agricultural Sciences, P.O. Box 234, SE-53223, \\ Skara, Sweden \\ Corresponding author:
}

Anna Olsson, Laboratory Animal Science, IBMC - Institute for Molecular and Cell Biology, and i3S - Institute for Research and Innovation in Health, University of Porto, Rua Alfredo Allen, 4200-135, Porto, Portugal

Email address : olsson@ibmc.up.pt

Originally published in Applied Animal Behaviour Science, 2019: 2018. https://doi.org/10.1016/j.applanim.2019.06.008 


\begin{abstract}
Perinatal mortality is a widespread problem in laboratory mouse breeding and is often manifested by the loss of the entire litter within the first days of life. High mortality is an animal health and welfare concern that violates the $3 \mathrm{R}$ principles of reduction and refinement. High pup mortality is often considered "normal" in mouse breeding and the underlying causes are poorly understood. This study investigated the role of the social environment on pup survival and parental behaviour in $\mathrm{C}_{57} \mathrm{BL} / 6$ mice. Before parturition, multiparous females were allocated to three treatments: single-housing $\left(\mathrm{SH}_{1} \mathrm{n}=54\right)$ or group-housing in trios of two females and a male, with group-housing further divided into trios with $\left(\mathrm{GH}_{1}, \mathrm{n}=20\right)$ or without $(\mathrm{GHo}, \mathrm{n}=35$ ) the presence of another litter. Mouse behaviour was recorded from $24 \mathrm{~h}$ before to $24 \mathrm{~h}$ after parturition. Mouse breeding performance (offspring survival and weight) was analysed using logistic and generalized linear models, and behaviours using logistic and multivariable linear models. We confirmed previous findings of high mortality rates for all treatments, but the highest rates were found in $\mathrm{GH}_{1}$ where half of the litters were lost entirely. Social environment had an impact on breeding performance. On the one hand, the presence of adult cagemates in GHo did not affect litter survival nor pup body weight at 20 days. Adult cagemates shared the work of breeding by performing nest building before and after litter birth, and parental care after birth. GHo and $\mathrm{GH}_{1}$ dams were less frequently seen performing nest building before and after parturition than $\mathrm{SH}$ dams. $\mathrm{GHo}$ and $\mathrm{GH}_{1}$ dams were also less frequently seen inside the nest and performing parental behaviour after parturition than were $\mathrm{SH}$ dams. On the other hand, the risks for litter and pup loss were dramatically increased by 2.3 and 1.8 times, respectively, in $\mathrm{GH}_{1}$ compared to GHo. Parturition lasted longer in $\mathrm{GH}_{1}$ than in $\mathrm{GHo}$ treatment. While dam behaviour did not differ between $\mathrm{GH}_{1}$ and $\mathrm{GHo}_{1} \mathrm{GH}_{1}$ adult cagemates spent less time performing parental care than did GHo cagemates. Plausible reasons for the higher mortality in the presence of another litter are insufficient parental care, competition for milk access, poor nest quality, and crushing of newborns by older pups in the nest. This study indicates that being born in a cage where there is already an older litter, so-called reproductive asynchrony, is a major risk factor for litter loss.
\end{abstract}

Key words: perinatal mortality, litter survival, asynchronous breeding, parental behaviour, mouse welfare.

Highlights:

- Perinatal mortality is frequent in laboratory mouse despite economic and ethical concerns

- $\quad$ The presence of adult cagemates (GHo) did not modulate litter survival

- The presence of a second litter $\left(\mathrm{GH}_{1}\right)$ increased the risk for litter loss up to $50 \%$

- Cagemates participated to breeding in $\mathrm{GHo}_{0}$ and $\mathrm{GH}_{1}$, reducing dam's parental investment

- Mouse behaviour differed in $\mathrm{GH}_{1}$ but disturbance by older pups may explain mortality 


\section{INTRODUCTION}

Early pup mortality is a widespread problem in laboratory mouse breeding but is often considered "normal". Often, the whole litter is lost within the first few days after birth, which substantially reduces the efficiency of animal breeding with subsequent economic consequences of having to maintain larger numbers of breeding animals. High mortality rates are also an animal health and welfare concern and the loss of large numbers of pups violates the 3 Rs principle (replacement, reduction, refinement), which was originally proposed by Russell and Burch (1959) and now is widely accepted as a guiding principle for the use of animals in experiments. Existing literature reports highly variable mortality rates during breeding: from nearly zero to 50\% in experimental studies (Reeb-Whitaker et al 2001; Inglis et al 2004; Cooper et al 2007; Whitaker et al 2007) and $12.6 \%$ reported for the same mouse strain $\left(\mathrm{C}_{57} \mathrm{BL} / 6\right)$ by a commercial breeder (The Jackson Laboratory, 2012). Our own data from several experimental studies and breeding colonies show $32-35 \%$ losses of the entire litter in C57BL/6 mice (Weber et al 2013b; unpublished data).

Perinatal mortality in laboratory mice typically occurs within the first three days of life (Weber 2015). Several factors have been suggested to increase newborn mortality including lack of environmental enrichment (Leidinger et al., 2018), routine husbandry (Reeb-Whitaker et al., 2001), genetic line (Brown et al., 1999), and maternal provision (Weber et al., 2016). Similar phenomena are relatively well-documented in farm animals, where the major causes are consistent across species: hypothermia, maternal and offspring underfeeding, inappropriate maternal behaviour, infections and injuries (for a review, see Mellor \& Stafford, 2004). As an altricial species, mouse pups are totally dependent on their mother for both nutrition and thermoregulation in early life; hence maternal behaviour is key to offspring survival (for a review, see Weber and Olsson, 2008).

Maternal experience is believed to affect pup survival and there is scientific evidence that primiparous mice are more prone to losing pups than are mice from second parities in both $\mathrm{C}_{57 \mathrm{BL} / 6 \mathrm{~J}}$ and DBA/2J mice (Brown et al., 1999). "Active" maternal behaviour (nest building and pup retrieval) and "passive" maternal behaviour (resting with, crouching over, and nursing pups) have both been related to litter survival (Brown et al., 1999; Weber et al., 2015). If females fail to provide appropriate care, infants are likely to die from hypothermia or starvation. Weber et al. (2016) found that females losing their litter performed less nest building behaviour during the last $24 \mathrm{~h}$ before parturition and spent less time nursing in the nest during the first $24 \mathrm{~h}$ after parturition. The provision of sufficient amounts of nesting material of good quality and/or nest boxes allows mice to protect their pups in nests and reduce mortality in cages where actual or perceived temperatures are below the thermoneutral range (Tsai et al 2003; Gaskill et al., 2009; Whitaker et al., 2009; Leidinger et al., 2018), as is often the case in individually-ventilated cages. For instance, providing nesting material has been demonstrated to enable mice to build sophisticated dome nests that enhance insulation and improve newborn survival up to 27\% (Gaskill et al., 2013a). In addition, prolonged parturition is related to poor pup viability and litter loss (Weber 2013a, 2015). The mother's emotional characteristics such as responsivity to an auditory stressor or anxiety levels have also been linked to pup mortality and cannibalism (Poley 1974; Carter et al. 2002).

Although several maternal and environmental factors have been associated with pup survival, the majority of the previous studies were performed with solitary dams, whereas pair, trio or harem housing is more practised in laboratories. Thus, two or more adults are usually present and often more than one litter. Because mice can communally nest and breed their litters (Manning et al., 1995; Bergmüller et al., 2007), the social environment may modulate mother behaviour and influence breeding performance. When given the choice, house mice are more likely to choose communal breeding with groups of genetically related individuals in front of solitary breeding (Harrison et al., 2018) but they are also capable of switching between these two strategies (Ferrari et al., 2019). Cooperative breeding provides benefits for the dam under certain conditions (Ferrari et al., 2016); it allows her to reduce attendance to nest and maternal care of her own litter (Auclair et al., 2014). Communal breeding can also benefit pups by creating a warmer micro-climate and improving opportunities for milk ingestion. From a management perspective, housing in trios is considered economically advantageous compared to single housing. 
The actual overall effect of trio housing on litter viability is unclear, as communal breeding of rodents has been associated with both higher (Manning et al., 1995) and lower (Ferrari et al., 2019) litter survival than in solitary breeding, while other studies have found no difference (Ebensperger et al., 2007). Housing mice in trios increases the likelihood of another litter being born in a cage where there is already an older litter, so-called reproductive asynchrony, which might affect the survival of the youngest pups. Schmidt et al. (2015) found reproductive asynchrony to decrease newborn survival in outbred laboratory mice derived from inbred strains. Surprisingly, while the impact of the social environment on behaviour and breeding performance is well-documented in house mice, with studies performed both in experimental (e.g. Ferrari et al., 2015) and natural (e.g. Auclair et al., 2014) settings, it has been neglected in inbred laboratory mice. The causes of perinatal mortality in laboratory mice is likely to be complex, involving several factors, including animal behaviour and husbandry practices. The aim of the present study was to investigate the influence of the social environment on the behaviour of female laboratory mice and their breeding performance, i.e. the survival and weight of their pups. We hypothesized that trio housing improves survival and increases pup weight through communal nesting and parental investment. We further hypothesized that the presence of another litter in the trio cages decreases newborn survival due to decreased parental care and crushing of newborn by older pups from another litter.

\section{MATERIALS AND METHODS}

\subsection{Animals and housing}

The data collection took place at the Biological Support Unit of the Babraham Institute (Cambridge, UK) over a period of three months (mid March to mid June 2017). A total of 109 litters of wild-type mice derived from $C_{57} \mathrm{BL} / 6 \mathrm{~J}$ parent stock were used. All mice were from the institute's regular breeding colony used to produce mice for experimental purposes. Five dams (4.6\%) were culled because they were in a poor clinical condition following parturitions that lasted for more than 48h. All the female mice were multiparous, in second $\left(P_{2}, n=31\right)$, third $\left(P_{3}, n=43\right)$, fourth $\left(P_{4}, n=26\right)$ or fifth $\left(P_{5}, n\right.$ = 9) parity, and were previously housed in trios. Each female was used as the focal dam only once, except five females which were studied twice. Thus, some cages were used twice, once with one female of the trio as the focal dam, and the next time with the second female as the focal dam. For additional details about the litters and conditions, see S1 Data litters.

Females were allocated to a social housing treatment approximately three days before parturition, either in singlehousing $(\mathrm{SH}, \mathrm{n}=54)$ or group-housing in trios of two females and a male $(\mathrm{n}=55)$. The group-housed animals were further divided into trios with $\left(\mathrm{GH}_{1}, \mathrm{n}=20\right)$ or without the presence of another litter $(\mathrm{GHo}, \mathrm{n}=35)$. Parities were balanced between treatments as far as possible.

Selected mice, including the females from the SH treatment, were identified by shaving the fur on a $3 \mathrm{~cm} 2$ area on the left or right thigh in females and the back in males. In addition, the females' tail was coloured using a blue or red sterile surgical grade marker. The marking procedure lasted on average $20 \mathrm{~s}$, did not require the use of anaesthetics, and allowed quick recognition of mice by human observers on video recordings during the light and dark phases. The mice were housed in individually ventilated cages (GM500 Filter@, Tecniplast, Italy; L x W x H, $391 \times 199 \times 160 \mathrm{~mm}$ ), mounted on a digital ventilated holding unit (DGM Sealsafe Plus Rack®, Tecniplast, Italy). Cages were supplied with an average of $48 \mathrm{~g}$ of soft wood flakes bedding (Eco-Pure Chips 6 Premium $\odot$, Datesand, United Kingdom) and $7.5 \mathrm{~g}$ of pure white paper rolls (Enrich-n'Nest@, Datesand, United Kingdom) as nesting material. A red polycarbonate tunnel (International Product Supplies Ltd, United Kingdom; $L \times \varnothing, 98.55 \times 50.80 \mathrm{~mm}$ ) was placed in each cage, suspended from the grid lid, to provide enrichment. Small amounts of the nesting and bedding materials were transferred from the previous cages when mice were moved to the experimental cages, to provide olfactory cues. Room temperature was kept at $20-24^{\circ} \mathrm{C}$ and relative humidity at 45-65\%. The animals were maintained on a 12:12 h light regime with lights gradually switched on from 07:00. Standard food pellets (CRM (P) Vacuum Pack, Dietex International Ltd, United Kingdom) and autoclaved water were offered ad libitum. After treatment allocation, the cages were moved to a separate rack within the breeding room, where video recording was performed on eight cages simultaneously. 


\subsection{Procedures on mice}

2.2.1. Pup investigation, counting and weighing

Cages were inspected once a day at 10:00 \pm 1 h to identify the day of birth for each litter (day o). Living and dead pups were counted at daily cage inspections from birth to day 4. Before parturition, inspection was performed by removing the cages from the rack and visually inspecting them without removing the lids. After parturition, inspection was performed by removing the cages from the rack, placing them under a fume hood where their lids and food hoppers were removed for a more accurate visual inspection. Pups were touched gently if needed to count them. Hands were disinfected with $70 \%$ ethanol prior to opening the cages and prior to touching the inside of the cages. All pups were weighed on day 20 using a high precision scale accurate to one centigram. The pups were weaned at $21 \pm 2$ days.

We validated and/or rectified litter size during subsequent video analyses of the first hours after the start of parturition (see below) to ensure that litter sizes recorded at birth were correct.

\subsection{Behavioural analyses}

Eight cages were recorded simultaneously and continuously from the last $24 \mathrm{~h}$ prior to parturition until $24 \mathrm{~h}$ after the first pup was born at 15 frames per second, through the use of eight HD-TVI bullet Infrared cameras (TWE-22MR, Mazi, Germany) connected to a digital video recorder (HTVR-o820MT, Mazi, Germany). Behaviours of the dam at parturition, all adults before and after the start of parturition and the older litter after the start of parturition were coded from the video recordings using 1-min scan sampling or continuous focal sampling (Table 1).

To analyse behaviours of the dam at parturition, the videos were scanned to detect the exact start and end times for parturition, defined as the times when the first and last pups were delivered. When the parturition lasted for less than 6 hours, the whole process was analysed thoroughly by continuous focal sampling. Otherwise, six 1-hour video sequences, as evenly spaced as possible, were selected and analysed. The later sampling technique was required in 12 of a total of 104 analysed parturitions, lasting from 7 hoo to 30 ho. Parturition behaviours displayed by the dam were recorded directly using Microsoft Excel software (version 16.0). Because long parturition has been associated with poor perinatal viability (Weber et al., 2013a), parturitions lasting more than $20 \mathrm{~h}$ were considered as indicative of labour complications.

To analyse behaviours of adults and the older litter, 12 20-min video sequences were selected, evenly distributed every $4 \mathrm{~h}$ from $24 \mathrm{~h}$ before to $24 \mathrm{~h}$ after the start of parturition. Adult behaviour was observed by either 1-min scan sampling or continuous focal sampling using the Observer XT 10.1 (Noldus Information Technology, The Netherlands). Another litter was present in the cage in $\mathrm{GH}_{1}$ treatment. The behaviour of the pups from the other litter was analysed for the $\mathrm{GH}_{1}$ treatment when these were old enough to be mobile. Of the $20 \mathrm{GH}_{1}$ cages, the behaviour of older pups was analysed in 16 cages, where the focal new litter was born when the existing older litter was 10 to 22 days old (asynchronous breeding). The older pup activity analysis was not performed on one litter, because the nest was not entirely visible on the video. In the four remaining cages, the litters were born less than 1 day apart (synchronous breeding).

A total of four observers performed the video analyses. The percentage of inter-observer agreement for each pair of observers was calculated for collecting inter- and intra-observer agreements using $240 \mathrm{~min}$ of randomly selected video sequences from the three treatments. Similarly, the percentage of intra-observer agreement was calculated for each observer using $580 \mathrm{~min}$ of video sequences. Inter- and intra-observer agreement was on average 97 and $97 \%$ for scan sampling, and 92 and $93 \%$ for focal sampling, respectively. The observers could not be blinded to treatments because the housing system was visible on the video recordings. However, the observers were blinded to mouse and litter characteristics and they did not know whether litters survived or died. 
Table 1. Ethogram of the adults' and pre-weaning pups' behaviours recorded before, during and after parturition.

\begin{tabular}{|c|c|c|c|c|}
\hline Animals observed & Sampling method & Category & Behavioural variables & Description \\
\hline Dam at parturition ${ }^{1}$ & Continuous focal sampling & Activity & $\begin{array}{l}\text { Parturition-related } \\
\text { behaviour }\end{array}$ & Stretching, standing on hind legs in labour posture, moving body up and down while giving birth \\
\hline \multirow{4}{*}{$\begin{array}{l}\text { All adults before and } \\
\text { after the start of } \\
\text { parturition }{ }^{2}\end{array}$} & \multirow[t]{3}{*}{ 1-min scan sampling } & \multirow[t]{2}{*}{ Location } & In nest & The two rear legs are in nest \\
\hline & & & Outside nest & The two rear legs are outside nest \\
\hline & & Activity & Nest building & Digging, carrying, pushing, moving nesting material with muzzle or paws \\
\hline & Continuous focal sampling & Activity & Parental care & $\begin{array}{l}\text { Sniffing, licking, grooming, handling, carrying newborn with paws or mouth. It also includes } \\
\text { situations in which the mouse is moving forelegs or head over the nest as to interact with pups } \\
\text { but pups are not visible. It does not concern parental care of the older pups in } \mathrm{GH} 1 \text { but only the } \\
\text { focal litter }\end{array}$ \\
\hline \multirow{3}{*}{$\begin{array}{l}\text { Other older litter after the } \\
\text { start of parturition }{ }^{3}\end{array}$} & \multirow[t]{3}{*}{ 1-min scan sampling } & \multirow[t]{2}{*}{ Location } & In nest & Number of pups in nest \\
\hline & & & Outside nest & Number of pups outside nest \\
\hline & & Activity & Active in nest & Number of pups moving, grooming, scratching jumping in nest \\
\hline
\end{tabular}

${ }^{1}$ The whole sequence of parturition from first pup birth to last pup birth was analysed when lasting less than 6 hours; otherwise, six 1-h video sequences were analysed over the parturition.

${ }^{2}$ Six 20-min video sequences before and six 20-min video sequences after the start of parturition were selected for the analysis of adults' behaviour.

${ }^{3} \mathrm{Six} 20$-min video sequences after the start of parturition were selected for the analysis of the other older litter behaviour. 
Analyses were carried out using SAS software (version 9.2; SAS Institute Inc., Cary, North Carolina, USA). For continuous data, normality of model residuals was tested using the Shapiro-Wilk test of normality.

First, the effects of social housing treatment and other risk factors on mouse breeding performance, i.e. offspring survival and weight, were analysed. Litters were characterized with respect to two traits: litter loss (binary trait: all pups died; not all pups died before weaning) and pup loss (binomial trait: number of pups dying within the first four days of life/number of pups born). The effects of treatment on litter loss and proportion of pups lost were analysed using all 109 litters. The unit of analysis was the litter. Litter loss was modelled by mixed logistic regression (SAS Glimmix procedure) and proportion of pups lost by generalized linear model taking the generalized estimating equation approach (McCullagh and Nelder, 1989; SAS Genmod procedure). In all models, a random-intercept effect of cage identity was included.

Independent variables considered as fixed effects were treatment $\left(\mathrm{SH}_{;} \mathrm{GHo}_{;} \mathrm{GH}_{1}\right)$, parity $\left(\mathrm{P}_{2}=\right.$ second parity; $\mathrm{P}_{3}=$ third parity; $P_{4}=$ fourth parity; $P_{5}=$ fifth parity), litter size at birth (small = 2-7 pups; medium = 8-9 pups; large = 10-14 pups), alopecia in one or more mice in the cage (presence; absence), kinship between the dam and the second female in the cage (dam's litter sister or not), cage location on the rack (location 1 to 8, from the left to the right of the rack), whether or not the dam's previous litter survived or not, month of birth (March; April; May; June) and weekday at birth (Monday-Friday, when technicians were present all day vs. Saturday-Sunday, when the lab was more quiet). Initially, the effects of each one of the independent variables (see S1 Data litters) were analysed by univariable models; variables with $\mathrm{P} \leq 0.25$ were regarded as eligible for subsequent analysis in a multivariable mixed logistic model in which the fixed effect of treatment was forced in. Starting with a full model, non-significant variables $(P>0.10)$, except treatment, were removed one by one until the model contained only significant variables. Litter loss and pup loss were unrelated by the presence of alopecia in the cage, kinship between the dam and the female cagemate, the cage location on the rack, the month of birth, the period of the week at birth or whether or not the previous litter survived. Thereafter, plausible interactions were tested and retained if significant $(P \leq 0.05)$. The final model of litter loss contained fixed effects representing treatment and litter size, and the final model of pup loss contained fixed effects of treatment and parity.

The effect of treatment on pup body weight at 20 days was analysed by mixed linear regression using the 70 remaining litters. Six litters were weaned on day 19 before the last weighing and so were not included. The unit of analysis was the pup $(n=519)$. Models were constructed using backward elimination as described above for the analysis of litter and pup loss. The final model contained fixed effects of treatment, parity and litter size, and a random-intercept effect of litter identity. Multiple comparisons between different levels of fixed effects were adjusted according to Tukey (Hayter et al., 1989).

Next, the effects of treatment on behaviours of adults and older pups were analysed in separate models for each behaviour $(104,52,52$ and 16 litters for the analysis of dam, female, male and older pups' behaviours, respectively). Five litters where the dams were culled due to labour complications were excluded. Analyses were performed at the video sequence level for behaviours recorded by continuous focal sampling, or the scan level for behaviours recorded by scan sampling. Initial models also included parity and litter size as fixed effects and litter identity as random intercept, as well as plausible interactions. Non-significant effects $(P>0.10)$ were then removed from the models one by one, always retaining treatment and litter identity. Behaviours recorded by instantaneous scan sampling were analysed using mixed logistic regression while behavioural variables recorded by continuous focal sampling were analysed using mixed linear models. An approximation of the degree of freedom was calculated according to the Satterthwaite equation (Satterthwaite, 1946). Data from parental care behaviour were skewed and lognormal distribution was used in the model. The estimates were then back-transformed to the original scale. Multiple comparisons between different levels of fixed effects were adjusted according to Tukey (Hayter et al., 1989). The effects of treatment and litter size on parturition duration were analysed using the non-parametric Kaplan-Meier method (SAS Lifetest procedure). This method utilizes censored data efficiently, i.e. dams being culled during parturition. Model results were expressed as predictive means \pm standard errors. 


\section{RESULTS}

\subsection{Breeding performance}

Litter size and parity were approximately balanced between treatments (see $S_{1}$ Data litters). Only 15 out of 109 litters had no pup loss at all (Figure 1.a). All litter losses except one took place within the first three days of life (four losses on day o, nine on day 1 , eight on day 2, three on day 3 , and one on day 5). The five dams that were culled due to their inability to give birth lost their few born pups some hours after birth and were considered as having lost their litter (see S2 Parturitions with labour complications).
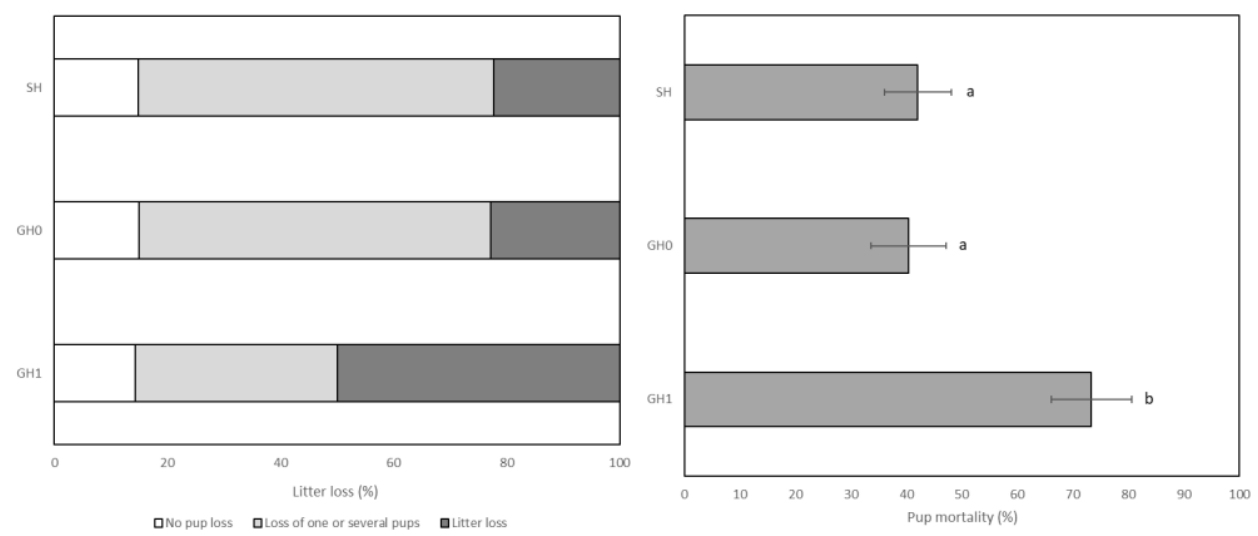

Fig. 1. a. Total percentage of complete litter loss, loss of one or several pups or no pup loss at all; b. Predicted mean percentage $( \pm \mathrm{SEM})$ of pup loss per treatment, for single-housed dams $(\mathrm{SH}, \mathrm{n}=54)$ and group-housed dams in trio with $\left(\mathrm{GH}_{1}, \mathrm{n}=20\right.$ ) or without ( $\left.\mathrm{GHo}, \mathrm{n}=35\right)$ the presence of another litter. a,b Means with different letters significantly differ $(P<0.05)$ between treatments.

The risk for litter loss was influenced by treatment (Table 2). According to the model, litter loss increased when another litter was present in the cage since the probability of losing a litter was 2.8 and 2.3 times higher in $\mathrm{GH}_{1}$ than in $\mathrm{SH}$ and $\mathrm{GHo}$, respectively $(\mathrm{P}=0.010$ and $\mathrm{P}=0.036)$. All the $10 \mathrm{GH} 1$ litters that died were litters that were born while 10 - to 22 -day old pups were present in the cage (asynchronous breeding). Individual pup mortality was also affected by treatment (Table 2). The risk for individual pup loss increased 1.7 and 1.8 times in $\mathrm{GH}_{1}$ compared to $\mathrm{SH}$ and $\mathrm{GHo}$, respectively (Figure 1.b, $\mathrm{P}$ $<0.001$ and $\mathrm{P}=0.001$ ). The Figure 2 shows that social environment had an impact on pup weight since $\mathrm{GH}_{1}$ pups were significantly heavier than $\mathrm{GHo}$ and $\mathrm{SH}$ pups at day $20(\mathrm{P}<0.001$ and $\mathrm{P}<0.001)$. However, parity also had an impact on pup body weight (see Table 2).

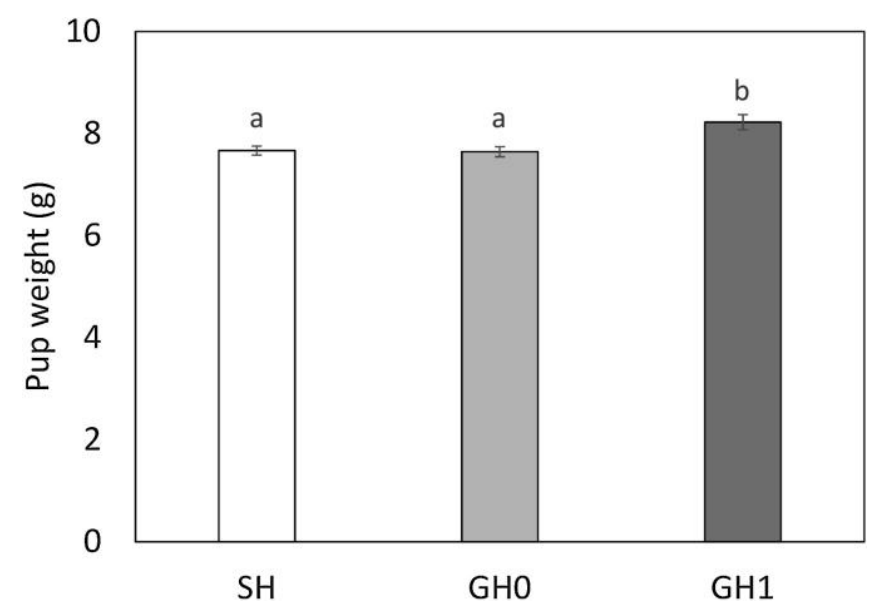

Fig. 2. Average individual weight ( $\pm \mathrm{SEM}$ ) of pups from single-housed dams $(\mathrm{SH})$ and group-housed dams in trio with $\left(\mathrm{GH}_{1}\right)$ or without ( $\mathrm{GHo}$ ) the presence of another litter, at 20 days old ( $\mathrm{n}=238,210$ and $71 \mathrm{for} \mathrm{SH}, \mathrm{GHo}$ and $\mathrm{GH} 1$, respectively). a, b Means with different letters significantly differ $(P<0.05)$ between treatments. 
Table 2. Summary of the multivariable models regarding breeding performance for litters from single-housed dams (SH) and group-housed dams in trio with (GH1) or without (GHo) the presence of another litter.

\begin{tabular}{|c|c|c|c|c|c|c|c|c|c|c|c|c|}
\hline \multirow[b]{2}{*}{ Variable $^{a}$} & \multirow[b]{2}{*}{ Level } & \multicolumn{4}{|l|}{ Litter loss ${ }^{b}$} & \multicolumn{4}{|l|}{ Pup loss ${ }^{b}$} & \multicolumn{3}{|c|}{ Pup weight at 20 days ${ }^{c}$} \\
\hline & & Coefficient & SE & $\mathrm{OR}$ & $P^{d}$ & Coefficient & SE & OR & $P^{d}$ & Coefficient & SE & $P^{\mathrm{d}}$ \\
\hline Intercept & & 0.02 & 0.47 & & 0.969 & -1.49 & 0.35 & & $<0.001$ & 7.80 & 0.10 & $<0.001$ \\
\hline \multirow[t]{3}{*}{ Treatment } & $\mathrm{SH}$ & 0 & & 1 & $(0.029)$ & 0 & & 1 & $(0.007)$ & 0 & & $(<0.001)$ \\
\hline & $\mathrm{GHO}$ & 0.26 & 0.59 & 1.30 & 0.655 & -0.07 & 0.32 & 0.93 & 0.828 & -0.02 & 0.10 & 0.828 \\
\hline & $\mathrm{GH}_{1}$ & 1.70 & 0.65 & 5.48 & 0.010 & 1.33 & 0.38 & 3.80 & 0.001 & 0.56 & 0.15 & $<0.001$ \\
\hline \multirow[t]{3}{*}{ Litter size $^{a}$} & Small & 0 & & 1 & $(0.001)$ & & & & & & & \\
\hline & Medium-size & -1.93 & 0.61 & 0.14 & 0.002 & & & & & & & \\
\hline & Large & -2.28 & 0.65 & 0.10 & $<0.001$ & & & & & & & \\
\hline \multirow[t]{4}{*}{ Parity ${ }^{b}$} & $\mathrm{P}_{2}$ & & & & & 0 & & & $(0.006)$ & 0 & & $(<0.001)$ \\
\hline & $P_{3}$ & & & & & 0.90 & 0.36 & 2.45 & 0.012 & -0.65 & 0.11 & $<0.001$ \\
\hline & $\mathrm{P}_{4}$ & & & & & 1.32 & 0.43 & 3.77 & 0.002 & -0.34 & 0.14 & 0.015 \\
\hline & $P_{5}$ & & & & & 2.47 & 0.64 & 11.84 & $<0.001$ & 0.45 & 0.27 & 0.100 \\
\hline
\end{tabular}


Table 3. Summary of the models on the impact of social housing treatment on parental behaviour before the start of parturition, for single-housed dams (SH, $\mathrm{n}=52$ ) and group-housed mice in trio with $(\mathrm{GH} 1, \mathrm{n}=2 \mathrm{O})$ or without $(\mathrm{GHO}, \mathrm{n}=32)$ the presence of another litter

\begin{tabular}{|c|c|c|c|c|c|c|c|c|}
\hline Behaviour & Subject & Variable & Level & Coefficient & SE & OR & $\begin{array}{l}\text { Predictive } \\
\text { mean }^{a}, \%\end{array}$ & $P^{\mathrm{b}}$ \\
\hline \multirow[t]{10}{*}{ In nest } & Dam & Intercept & & 1.64 & 0.16 & \multirow{4}{*}{$\begin{array}{l}1 \\
0.74 \\
1.24\end{array}$} & & \multirow[b]{2}{*}{$(0.267)$} \\
\hline & & \multirow[t]{3}{*}{ Treatment } & $\mathrm{SH}$ & 0 & & & 83.8 & \\
\hline & & & $\mathrm{GHO}$ & -0.30 & 0.26 & & 79.3 & 0.248 \\
\hline & & & $\mathrm{GH}_{1}$ & 0.22 & 0.30 & & 86.6 & 0.476 \\
\hline & \multirow[t]{3}{*}{ Female cagemate } & Intercept & & 0.99 & 0.19 & \multirow{3}{*}{$\begin{array}{l}1 \\
1.42\end{array}$} & & \multirow{3}{*}{$(0.261)$} \\
\hline & & \multirow[t]{2}{*}{ Treatment } & $\mathrm{GHO}$ & 0 & & & 72.8 & \\
\hline & & & $\mathrm{GH}_{1}$ & 0.35 & 0.31 & & 79.3 & \\
\hline & \multirow[t]{3}{*}{ Male cagemate } & Intercept & & 1.18 & 0.16 & \multirow{3}{*}{$\begin{array}{l}1 \\
1.11\end{array}$} & & \multirow{3}{*}{$(0.687)$} \\
\hline & & \multirow[t]{2}{*}{ Treatment } & $\mathrm{GHO}$ & 0 & & & 76.5 & \\
\hline & & & $\mathrm{GH}_{1}$ & 0.11 & 0.26 & & 78.4 & \\
\hline \multirow[t]{10}{*}{ Nest building } & \multirow[t]{4}{*}{ Dam } & Intercept & & 2.13 & 0.13 & \multirow{4}{*}{$\begin{array}{l}1 \\
0.50 \\
0.29\end{array}$} & & \multirow{4}{*}{$\begin{array}{l}(<0.001) \\
0.0027 \\
<0.001\end{array}$} \\
\hline & & \multirow[t]{3}{*}{ Treatment } & $\mathrm{SH}$ & 0 & & & 10.6 & \\
\hline & & & $\mathrm{GHO}$ & 0.69 & 0.22 & & 5.6 & \\
\hline & & & $\mathrm{GH}_{1}$ & 1.25 & 0.27 & & 3.3 & \\
\hline & \multirow[t]{3}{*}{ Female cagemate } & Intercept & & -3.92 & 0.21 & \multirow{3}{*}{$\begin{array}{l}1 \\
1.38\end{array}$} & & \multirow{3}{*}{$(0.327)$} \\
\hline & & \multirow[t]{2}{*}{ Treatment } & $\mathrm{GHO}$ & 0 & & & 1.9 & \\
\hline & & & $\mathrm{GH}_{1}$ & 0.32 & 0.32 & & 2.7 & \\
\hline & \multirow[t]{3}{*}{ Male cagemate } & Intercept & & -4.62 & 0.21 & \multirow{3}{*}{$\begin{array}{l}1 \\
2.55\end{array}$} & & \multirow{3}{*}{$(0.002)$} \\
\hline & & Treatment & $\mathrm{GHO}$ & 0 & & & 1.0 & \\
\hline & & & $\mathrm{GH}_{1}$ & 0.94 & 0.29 & & 2.5 & \\
\hline
\end{tabular}

Data are provided from 1-min scan sampling analysis and are presented as predictive means. The predictive means represent the percentage of scans in which the behaviour was recorded. b Joint test of treatment effect between parenthesis. 


\subsection{Mouse behaviour}

3.2.1. Prepartum behaviour

A significant relationship was found between social housing treatment and dam behaviour recorded during the last $24 \mathrm{~h}$ before the start of parturition (Table 3). Dams housed in trios were less frequently seen performing nest building behaviour than single-housed dams; Indeed, the probability to see SH dams performing nest building was 1.9 and 3.2 times higher than for $\mathrm{GHo}$ and $\mathrm{GH}_{1}$ dams, respectively $(\mathrm{P}=0.003$ and $\mathrm{P}<0.001)$. However, when housed in trios, adult cagemates were also involved in nest building irrespective if another litter was present $\left(\mathrm{GH}_{1}\right)$ or not $(\mathrm{GHo})$.

\subsubsection{Parturition behaviour}

Parturition took more than $20 \mathrm{~h}$ for six (5.5\%) dams and two of them lost their litter (see S2 Parturitions with labour complications). The time interval between the first and the last pup birth was related to treatment and litter size; parturition lasted longer for $\mathrm{GH}_{1}$ treatment than for GHo treatment (Figure 3, time to median: 234.0 (128.0-546.0) and 134.5 (109.0-156.0), respectively, $\mathrm{P}=0.013$ ). The parturition duration was intermediate for $\mathrm{SH}$ treatment (163.0 (128.0195.0)) and did not differ from other treatments. The duration of parturition-related behaviour did not differ between treatments $(P=0.182)$. Also, longer parturition duration and longer parturition-related behaviours were recorded in larger litters.

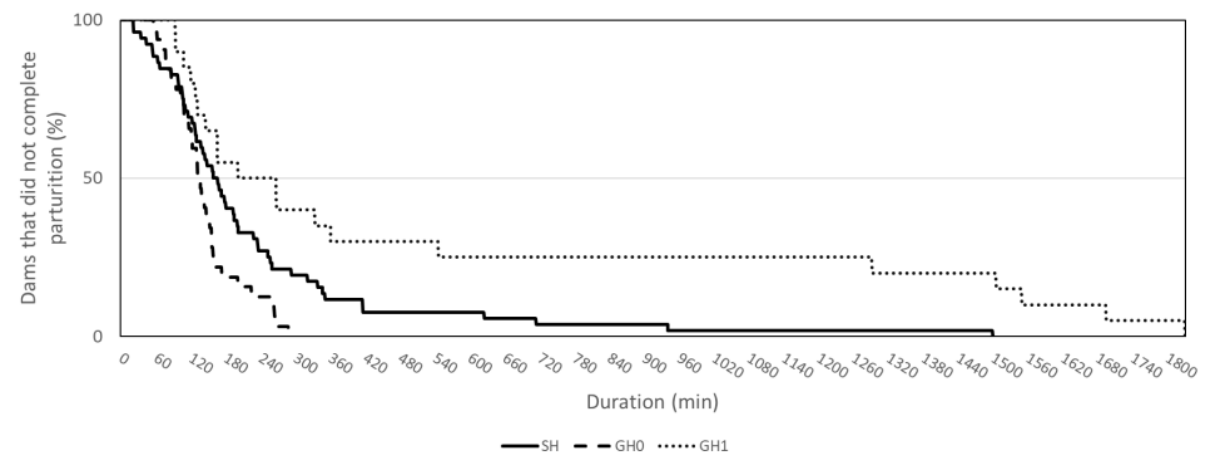

Fig. 3. Survivor curve of dam's parturition duration for single-housed dams $(\mathrm{SH}, \mathrm{n}=52)$ and group-housed dams in trio with $\left(\mathrm{GH}_{1}, \mathrm{n}=20\right)$ or without $(\mathrm{GHo}, \mathrm{n}=32)$ the presence of another litter.

\subsubsection{Postpartum behaviour}

Dam behaviour performed the first $24 \mathrm{~h}$ after the start of parturition was modulated according to the social housing treatment (Table 4). Dams housed in trios were seen less frequently in the nest and spent less time performing parental behaviours; i.e. parental care and nest building. Single-housed dams spent twice as much time performing parental care as group-housed dams $\left(\mathrm{P}<0.001\right.$ and $\mathrm{P}<0.001$ for $\mathrm{GHo}_{0}$ and $\mathrm{GH}_{1}$, respectively). There was also an effect of litter size, in that dams with small litters performed less parental care than dams with medium-sized and large litters. The time spent by SH dams on nest building was 2.8 and 2.0 times less compared to dams from GHo and $\mathrm{GH}_{1}$ treatments $(\mathrm{P}<0.001$ and $\mathrm{P}<0.001)$.

Male and female cagemates from $\mathrm{GHo}_{0}$ and $\mathrm{GH}_{1}$ treatments contributed to raising pups by taking care of the focal newborns and performing nest building (Table 4). Besides, they were seen performing nest building more frequently than the dams after their parturition. The amount of time that cagemates allocated to parental care was 1.5 and 1.5 times lower, for the female and the male respectively, in $\mathrm{GH}_{1}$ than in $\mathrm{GHo}$ treatments $(\mathrm{P}=0.035$ and $\mathrm{P}=0.021)$. Finally, the $\mathrm{GH}_{1}$ males were less often seen in the nest than $G$ Ho males $(P=0.012)$ but were often seen in the plastic hanging tunnel (personal observation). 
Table 4. Summary of the models on the impact of social housing treatment on parental behaviour after the start of parturition, for single-housed dams $(\mathrm{SH}, \mathrm{n}=52)$ and group-housed mice in trio with (GH1, $\mathrm{n}=20)$ or without $(\mathrm{GHO}, \mathrm{n}=32)$ the presence of another litter.

\begin{tabular}{|c|c|c|c|c|c|c|c|c|}
\hline Behaviour & Subject & Variable & Level & Coefficient & SE & OR & $\begin{array}{l}\text { Predictive } \\
\text { mean, (\%) }\end{array}$ & $P^{\mathrm{d}}$ \\
\hline \multirow[t]{10}{*}{ In nest ${ }^{a}$} & Dam & Intercept & & -2.59 & 0.14 & & & \multirow[b]{2}{*}{$(<0.001)$} \\
\hline & & \multirow[t]{3}{*}{ Treatment } & $\mathrm{SH}$ & 0 & & & 93.0 & \\
\hline & & & $\mathrm{GHO}$ & 1.73 & 0.21 & \multirow{2}{*}{$\begin{array}{l}5.62 \\
5.19\end{array}$} & 70.4 & $<0.001$ \\
\hline & & & $\mathrm{GH}_{1}$ & 1.65 & 0.24 & & 72.0 & $<0.001$ \\
\hline & \multirow[t]{3}{*}{ Female cagemate } & Intercept & & -2.55 & 0.16 & \multirow{3}{*}{$\begin{array}{l}1 \\
1.18\end{array}$} & & \multirow{3}{*}{$(0.523)$} \\
\hline & & \multirow[t]{2}{*}{ Treatment } & $\mathrm{GHO}$ & 0 & & & 92.8 & \\
\hline & & & $\mathrm{GH}_{1}$ & 0.16 & 0.25 & & 91.6 & \\
\hline & \multirow[t]{3}{*}{ Male cagemate } & Intercept & & -2.24 & 0.18 & \multirow{3}{*}{$\begin{array}{l}1 \\
2.13\end{array}$} & & \multirow{3}{*}{$(0.012)$} \\
\hline & & \multirow[t]{2}{*}{ Treatment } & $\mathrm{GHO}$ & 0 & & & 90.4 & \\
\hline & & & $\mathrm{GH}_{1}$ & 0.76 & 0.29 & & 81.6 & \\
\hline \multirow{10}{*}{$\begin{array}{l}\text { Nest } \\
\text { building }\end{array}$} & \multirow[t]{4}{*}{ Dam } & Intercept & & 1.71 & 0.07 & \multirow{4}{*}{$\begin{array}{l}1 \\
3.11 \\
2.24\end{array}$} & & \multirow{3}{*}{$\begin{array}{l}(<0.001) \\
<0.001\end{array}$} \\
\hline & & \multirow[t]{3}{*}{ Treatment } & $\mathrm{SH}$ & 0 & & & 15.3 & \\
\hline & & & $\mathrm{GHO}$ & 1.13 & 0.12 & & 5.5 & \\
\hline & & & $\mathrm{GH}_{1}$ & 0.81 & 0.14 & & 7.5 & $<0.001$ \\
\hline & \multirow[t]{3}{*}{ Female cagemate } & Intercept & & 2.08 & 0.09 & \multirow{3}{*}{$\begin{array}{l}1 \\
0.77\end{array}$} & & \multirow{3}{*}{ (0.073) } \\
\hline & & \multirow[t]{2}{*}{ Treatment } & $\mathrm{GHO}$ & 0 & & & 11.1 & \\
\hline & & & $\mathrm{GH}_{1}$ & -0.26 & 0.14 & & 13.9 & \\
\hline & \multirow[t]{3}{*}{ Male cagemate } & Intercept & & 2.00 & 0.10 & \multirow{4}{*}{$\begin{array}{l}1 \\
1.15 \\
-\end{array}$} & & \multirow{3}{*}{$(0.414)$} \\
\hline & & \multirow[t]{2}{*}{ Treatment } & $\mathrm{GHO}$ & 0 & & & 11.9 & \\
\hline & & & $\mathrm{GH}_{1}$ & 0.14 & 0.17 & & 10.5 & \\
\hline \multirow[t]{13}{*}{$\begin{array}{l}\text { Parental } \\
\text { care }^{\mathrm{b}}\end{array}$} & Dam & Intercept & & 2.32 & 0.09 & & & \\
\hline & & Treatment & $\mathrm{SH}$ & 0 & & - & 8.1 & $(<0.001)$ \\
\hline & & & $\mathrm{GHO}$ & -0.72 & 0.11 & - & 3.9 & $<0.001$ \\
\hline & & & $\mathrm{GH}_{1}$ & -0.75 & 0.13 & - & 3.9 & $<0.001$ \\
\hline & & Litter size $^{c}$ & Small & 0 & & & 3.4 & $(<0.001)$ \\
\hline & & & Medium & 0.62 & 0.13 & - & 6.3 & $<0.001$ \\
\hline & & & Large & 0.55 & 0.12 & - & 5.8 & $<0.001$ \\
\hline & Female cagemate & Intercept & & 1.08 & 0.13 & - & & \\
\hline & & Treatment & $\mathrm{GHO}$ & 0 & & - & 4.3 & $(0.035)$ \\
\hline & & & $\mathrm{GH}_{1}$ & 0.36 & 0.17 & - & 2.8 & \\
\hline & Male cagemate & Intercept & & -0.42 & 0.12 & - & & \\
\hline & & Treatment & $\mathrm{GHO}$ & 0 & & - & 0.9 & $(0.021)$ \\
\hline & & & $\mathrm{GH}_{1}$ & 0.35 & 0.15 & 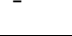 & 0.6 & \\
\hline
\end{tabular}

a Data of location in nest and nest building are provided from 1-min scan sampling analysis and are presented as predictive means. The predictive means represent the percentage of scans in which the behaviour was recorded. ${ }^{b}$ Data of parental care are provided from the continuous focal sampling analysis and lognormal distribution was used in the model. The back-transformed means represent the percentage of time during which the behaviour was performed. Coefficients from this model are on the log scale.

' Litter size is categorised as small (i.e. 2 to 7 pups, n=25), medium-sized (i.e. 8 to 9 pups, n=41) or large (i.e. 10 to 14 pups, $\mathrm{n}=38$ ).

d Joint test of treatment and litter size effect between parenthesis. 
Sixteen out of $20 \mathrm{GH}_{1}$ litters were born while 10 to 22 -day old pups were present, i.e. older pups were already mobile. For these cages, behaviour of the mobile older pups was analysed. The risk for litter loss was not related to how active the older pups were in the nest $(P=0.861)$ but it was influenced by the total number of older pups counted in the nest across scans $(P=0.052)$. The risk for litter loss was higher when the litter size of the older litter was greater $(P=0.057)$. Images in Figure 4 depict the influence of social environment on nest quality. Nests from single-housed dams were small, and either flat or cup-shaped, while nests from group-housed mice were larger, and sometimes spread out or flat. The presence of older pups exacerbated the poor nest quality found in group-housed mice, suggesting that older pups caused nest disturbance and decreased nest quality.

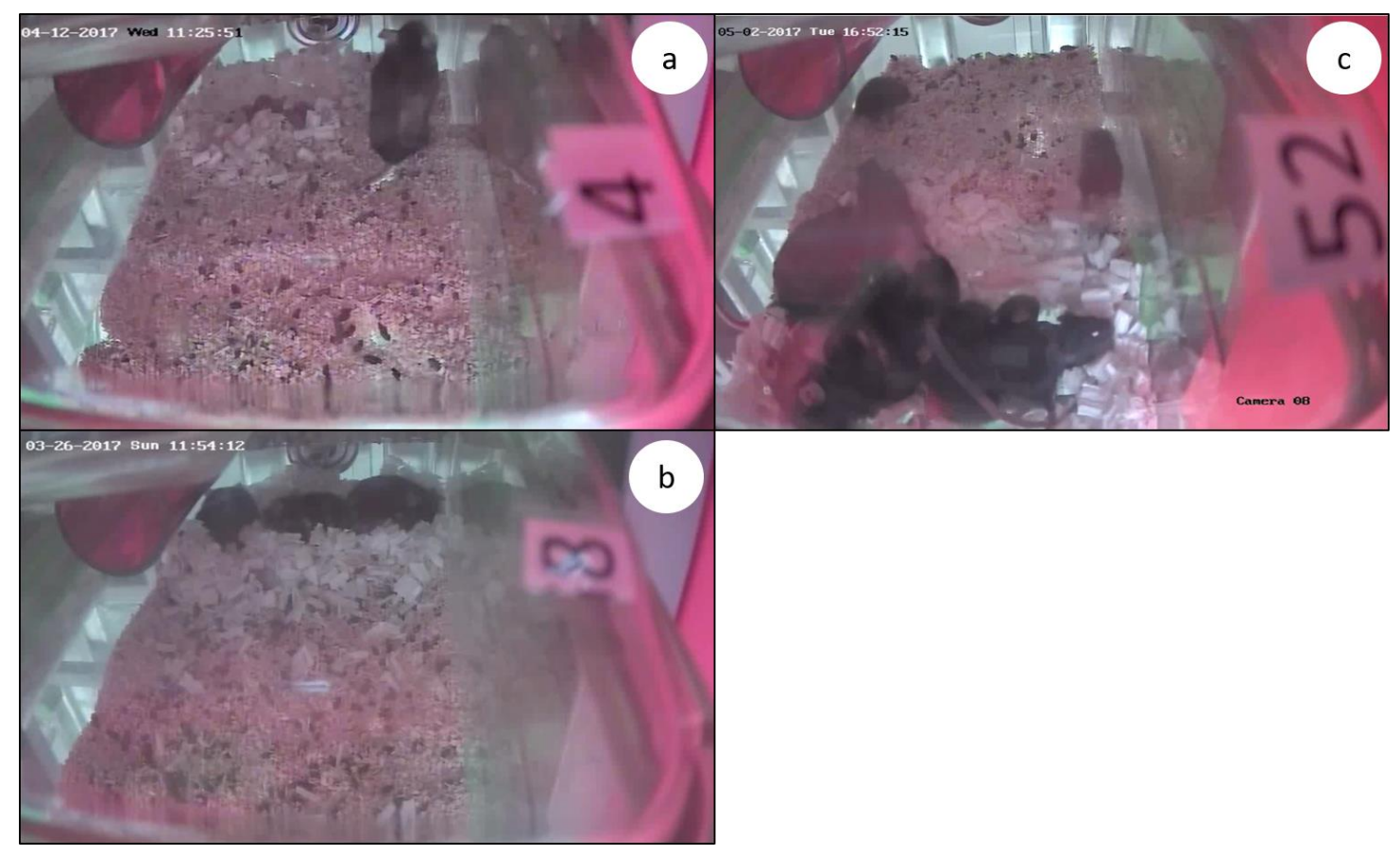

Fig. 4. Pictures of the impact of social environment on nest quality in, a: single-housed dams (SH); b: group-housed in trio without the presence of another litter $(\mathrm{GHo})$ and; c: group-housed in trio with the presence of another older litter $\left(\mathrm{GH}_{1}\right)$. 
Pup mortality is a persistent but poorly understood problem in laboratory mouse breeding. In this paper, we investigated the role of social factors on pup survival, as well as parental behaviour in $\mathrm{C}_{57} \mathrm{BL} / 6$ mice. We confirmed previous findings of high mortality rates with pups dying primarily within three days post-partum, independently of the type of social housing. However, social environment had an impact on the severity of the problem. The most important factor affecting mortality was the presence of older pups in the cage at birth since litter loss dramatically increased (up to $50 \%$ ) when they were present.

\subsection{Breeding performance}

Consistent with previous studies on $\mathrm{C}_{57} \mathrm{BL} / 6$ laboratory mice (Weber et al., 2013b, 2016), loss of the entire litter was frequent. In addition, most of the surviving litters were reduced due to the death of several pups within the first days of life, resulting in even higher overall pup mortality. Because mice have evolved cooperative breeding strategies (Auclair et al., 2014), we initially hypothesized that the presence of communal breeders would improve breeding performance in laboratory mice, similar to what König (1993) observed in house mice. However, in cages with only one litter present, neither litter and pup survival nor pup weight at $20 \mathrm{~d}$ differed between breeding mice housed in trios or solitary. This is consistent with the results reported by Heiderstadt et al. (2014) in their comparison of pup survival between single-bred and communally-bred (three dams and their litters) mice and Wasson (2017) in their comparison between pair-bred and trios-bred mice, both studies using mice from various background strains, including C57BL/6.

In the present study, the presence of another litter within the cage was the key factor modulating reproductive output and it affected newborn survival in several ways. First, the presence of another litter at birth increased the risk of losing the entire litter within the first days of life from $22-23 \%$ to $50 \%$. Second, the percentage of overall pup loss also nearly doubled in presence of another litter since it increased by 1.7 and 1.8 times in $\mathrm{GH}_{1}$ compared to $\mathrm{SH}$ and GHo. Reproductive asynchrony, i.e. when a litter is born while another is still present, had previously been identified as a risk factor for newborn mortality in outbred laboratory mice derived from inbred strains by Schmidt et al. (2015). The authors suggested that the increase in newborn mortality in the presence of older pups could be due to infanticide performed by the female cagemates as a strategy to improve their own fitness. According to Schmidt et al. (2015), synchronous breeding may prevent infanticide and litter loss since mice may be unable to discriminate similarly aged newborn. Although infanticide occurs in communally breeding mice, the authors did not directly observe mice but assumed that pups were killed since they were disappearing between cage-checking episodes. Detailed behaviour analysis targeting potential events of active killings suggested that infanticide is rare and that most pups are already dead when eaten (Weber et al., 2013a). Hence, it is possible that Schmidt et al. (2015) overestimated the amount of infanticide. Rather, impaired parental behaviour and disturbance by or competition with the other litter may be the main causes of early death.

The presence of another litter in the cage also played a role in pup body weight since $\mathrm{GH}_{1}$ pups were the heaviest. This finding supports the results from Heiderstadt et al. (2014) where pups from three litters communally bred by three dams showed higher body weight at weaning than pups bred by solitary dams. We did not weigh pups at birth in order to avoid interference with mouse behaviour and potential increased mortality. Several hypotheses have been formulated in order to explain the body weight difference between social environments. The presence of three breeding mice (two females and a male) in $\mathrm{GH}_{1}$ may be beneficial through improved thermoregulation and parental behaviours (Gerlach and Bartmann, 2002), but the effect should be maximised if two females rather than one nurse the litter, which is likely to have been the case for $\mathrm{GH}_{1}$ cages where both females were lactating since both were breeding litters. The death of many neonates from the litters in the $\mathrm{GH}_{1}$ group may have allowed the milk available to be redistributed to fewer surviving pups. The way in which milk production is correlated with litter size is not clear. An earlier study found a positive correlation (Knight et al., 1986), but in a study of single and communally nursing females, Ferrari and co-workers (2015) found no correlation between milk production and own litter size. In contrast, communally nursing females produced more milk when the total number of pups in the nest (own and alien) was greater (Ferrari et al 2015). The relationship between the social environment and milk yield and consumption should be further investigated. 
The parity and the size of a newborn litter also had an influence on breeding performance. On the one hand, the probability for litter survival was reduced in small litters ( 2 to 7 pups at birth) compared to medium-sized ( 8 to 9 pups at birth) and large ones (10 to 14 pups at birth), in contrast with reports from Ebensperger et al. (2007) who did not find a relationship between litter size and litter survival in degus. According to the parental investment theory, mice should base their investment on expected benefits and so invest more energy in larger litters (Maestripieri and Alleva, 1991; Ardia, 2007); and in some cases, abandonment of the small litters may be an adaptive strategy (Mendl, 1994). On the other hand, breeding success was found to decrease with increasing parities. Previous studies demonstrated that primiparous females had lower breeding success than multiparous females, possibly due to inexperience (Brown et al., 1999), but Weber et al. (2013b) did not find any parity effect on litter loss between multiparous females. In order to avoid a possible effect of lack of experience, we included only females from the second to the fifth parity. Instead, the risk for pup loss increased with parities. Litter size has been demonstrated to be higher between the second and the fourth parity compared to the first and fifth parity (Knight et al., 1986). Hence, parity and litter size effects may have been confounded in this study; however since parity and litter size were balanced between treatments, these effects were not confounded with treatment.

\subsection{Parental investment and disturbance by the other litter}

Presence of cagemates modulated dam behaviour both before and after parturition. The parturition duration did not differ between $\mathrm{SH}$ and GHo dams. However, solitary dams were seen more frequently performing nest building than dams housed in trios, both before and after parturition. Solitary dams also performed more parental pup care after parturition. The litter size has an influence on parental care since larger litters require more investment from the mother than smaller litters (Johnson et al., 2001) and we found that dams with medium-sized and large litters spent more time sniffing licking, grooming and handling the pups than did dams with small litters. During the first days of life, newborns fully depend on the dams for nutrition and thermoregulation (König and Markl, 1987; Gaskill et al., 2013b) and parental investment in nursing and nest building is crucial for perinatal survival (Bult \& Lynch, 1997; Bond et al., 2002). Communal breeders share the cost of breeding and their parental investment may allow the dam to reallocate energy in self-oriented activities (Bergmüller et al., 2007).

Female cagemates in $\mathrm{GHo}_{0}$ and $\mathrm{GH}_{1}$ treatments were often seen taking care of focal newborn pups at birth (i.e. sniffing, licking, grooming, handling), even occasionally pulling a pup from the birth canal while the dam was giving birth (personal observation). This was rather rare in males. As expected, the female cagemate, and to a lower extent the male cagemate, in $\mathrm{GHo}_{\mathrm{H}}$ and $\mathrm{GH}_{1}$ treatments were involved in pup rearing since they were seen sniffing, licking, grooming or handling pups as soon as these were born. They were seen performing nest building in less than 3 percent of scans before parturition. and more than 10.5 percent of scans after parturition. In fact, the female and male cagemates from $\mathrm{GHo}$ and $\mathrm{GH}_{1}$ treatments spent twice as much time as the dams performing nest building in the first $24 \mathrm{~h}$ after parturition. The finding that cagemates were highly involved in nest building after litter birth, a component of parental behaviour in mouse (Bond et al., 2002), suggests that the dams had more time to nurse and take care of pups. However, the presence of two other adults in the cage did not improve pup survival.

The presence of another litter in the cage had an impact on adult behaviour. The only behaviour that differed between dams housed in trio with $\left(\mathrm{GH}_{1}\right)$ or without $(\mathrm{GHo})$ the presence of another litter was parturition. Parturition duration and parturition-related behaviour were mostly dependent on the litter size but the duration of parturition lasted longer in $\mathrm{GH}_{1}$ compared to GHo treatment. Labour complications are relatively common in $\mathrm{C}_{57} \mathrm{BL} / 6$ laboratory mice and some parturitions lasted more than $20 \mathrm{~h}$ in the present study. This was especially evident in the $\mathrm{GH}_{1}$ treatment, which contained five of the six females that had long-lasting parturitions. It is possible that $\mathrm{GH}_{1}$ females were disturbed by the presence of the other litter and that this prolonged labour. Prolonged parturition-related behaviours have been related to litter loss (Weber et al., 2016). Despite this probable disturbance caused by the other litter, none of the $\mathrm{GH}_{1}$ dams failed to give birth while two SH dams and three GHo dams had to be culled due to dystocia. 
Although dam behaviour before and after parturition did not differ between $\mathrm{GHo}_{\mathrm{H}}$ and $\mathrm{GH}_{1}$, parental behaviour of cagemates did. Both female and male cagemates spent less time performing parental care of the studied dam's pups when another litter was present than when it was absent. The total amount of time spent taking care of the focal litter by all the three adults represents a noticeable reduction of $20 \%$ of time in $\mathrm{GH}_{1}$ compared to GHo treatment. The finding that $\mathrm{GH}_{1}$ cagemates are less involved in parental care than GHo cagemates may provide part of the explanation for the lower breeding success in this treatment. There are at least two explanations for lower involvement in parental care. First, the $\mathrm{GH}_{1}$ female cagemates had their own pups to care for, thus may have spent less energy to care for the focal dam's newborn, as they can discriminate their own, older pups and those of the other female (Schmidt et al., 2015). Second, the $\mathrm{GH}_{1}$ male cagemates could have been disturbed by the presence of mobile older pups, as the adult males spent less time in the nest and more time in the plastic hanging tunnel when older pups were present (personal observation), possibly to isolate themselves from the agitation in the nest.

Sixteen out of $20 \mathrm{GH}_{1}$ litters were born while mobile older pups were present and all the $\mathrm{GH}_{1}$ litters that died were born under these conditions. The older age of the other litter, rather than the presence of another litter in itself, is suggested to be the cause of the higher newborn mortality in this treatment, in agreement with Schmidt et al. (2015). Housing mice in trios increases the likelihood of reproductive asynchrony, i.e. when a litter is born in a cage while an older litter is already present in the cage. In addition to their impact on adult behaviour described above, older pups may crush or push newborns to the edge of the nest and cause nest disturbance that may decrease pup survival. The larger the size of the older litter, the higher the risk of newborn mortality. In this context, a limitation of this study is that we were unable to observe older pups' behaviour in sufficient detail to determine if older pups may have killed the newborns either directly by crushing the youngest or indirectly by causing nest disturbance, pushing newborns out from the warmth of the nest or competing for milk access. Post-mortem examinations of newborns may allow determining the causes of death and see e.g., whether there are bruises and lesions on pups born while another older litter was already present in the cage (CapasPeneda et al., 2019).

5. Conclusion

Perinatal mortality was common in this study and the presence of another litter was associated with a higher risk of litter loss. Although both the male and female cagemates were involved in pup caretaking and there was an associated reduction of parental investment from the dam, their presence did not increase pup survival. In contrast, the presence of another litter was found to be related with prolonged dam parturition and decreased parental care from the male and female's cagemates to the focal newborns that could in turn increase pup mortality. Reproductive asynchrony, which is characterized by a big age difference between newborns and another litter already present in the nest, more than the presence of another litter per se, seems to be the key factor for high pup mortality. Strategies to avoid housing two or more litters of different age together should be developed in order to reduce the occurrence of litter loss. Texttext 


\section{Acknowledgements}

The authors would like to thank Paula Sofia Vilares Gouveia and Sara Capas Peneda who participated in the behavioural analyses, and all the staff at the Biological Support Unit of the Babraham Institute for their interest and support in the project and the care of the animals. This work was financed by FEDER - Fundo Europeu de Desenvolvimento Regional funds through the COMPETE 2020 Operacional Programme for Competitiveness and Internationalisation (POCI), Portugal 2020, and by Portuguese funds through FCT - Fundação para a Ciência e a Tecnologia/Ministério da Ciência, Tecnologia e Ensino Superior in the framework of the project PTDC/CVT-WEL/1202/2014 (POCI-010145-FEDER-016591).

\section{References}

Ardia, D. R. 2007. Site- and sex-level differences in adult feeding behaviour and its consequences to offspring quality in tree swalllows (Tachycineta bicolor) following brood-size manipulation. Canadian Journal of Zoology, 85, 847-854. doi: https://doi.org/10.1139/Zo7-070

Auclair, Y., König, B., Ferrari, M., Perony, N., Lindholm, A. K. 2014. Nest attendance of lactating females in a wild house mouse population: benefits associated with communal nesting. Animal Behaviour, 92, 143-149. doi: https://doi.org/10.1016/j.anbehav.2014.03.008

Bergmüller, R., Johnstone, R. A., Russell, A. F., Bshary, R. 2007. Integrating cooperative breeding into theoretical concepts of cooperation. Behavioural Processes, 76(2), 61-72. doi: https://doi.org/10.1016/j.beproc.2007.07.001

Bond, T. L., Neumann, P. E., Mathieson, W. B., Brown, R. E. 2002. Nest building in nulligravid, primigravid and primiparous $\mathrm{C}_{57} \mathrm{BL} / 6 \mathrm{~J}$ and $\mathrm{DBA} / 2 \mathrm{~J}$ mice (Mus musculus). Physiology \& Behavior, 75(4), 551-555.

Brown, R. E., Mathieson, W. B., Stapleton, J., Neumann, P. E. 1999. Maternal behavior in female C57BL/6J and DBA/2J inbred mice. Physiology \& Behavior, 67(4), 599-605.

Bult, A., Lynch, C. B. 1997. Nesting and fitness: lifetime reproductive success in house mice bidirectionally selected for thermoregulatory nest-building behavior. Behavior Genetics, 27(3), 231240.

Capas-Peneda, S., Morello, G., Gilbert, C., Olsson, A. 2019. Development of a necropsy protocol for newborn mice. 14th FELASA Congress 2019. Prague, Czech Republic.

Carter, D. B., Kennett, M. J., Franklin, C. L. 2002. Use of perphenazine to control cannibalism in DBA/1 mice. Comparative Medicine, 52(5), 452-455.

Cooper, J. C., Dealtry, G. B., Ahmed, M. A., Arck, P. C., Klapp, B. F., Blois, S. M., Fernández, N. 2007. An impaired breeding phenotype in mice with a genetic deletion of beta-2 microglobulin and diminished MHC class I expression: role in reproductive fitness. Biology of Reproduction, 77(2), 274279. doi: https://doi.org/10.1095/biolreprod.106.057125

Ebensperger, L. A., Hurtado, M. J., León, C. 2007. An experimental examination of the consequences of communal versus solitary breeding on maternal condition and the early postnatal growth and survival of degu, Octodon degus, pups. Animal Behaviour, 73(1), 185-194. doi: https://doi.org/10.1016/j.anbehav.2006.06.004 
Ferrari, M., Lindholm, A. K., König, B. 2015. The risk of exploitation during communal nursing in house mice, Mus musculus domesticus. Animal Behaviour, 110, 133-143. doi: https://doi.org/10.1016/j.anbehav.2015.09.018

Ferrari, M., Lindholm, A. K., König, B. 2016. A reduced propensity to cooperate under enhanced exploitation risk in a social mammal. Proceeding of the Royal Society B: Biological Science, 283(1830). doi: https://doi.org/10.1098/rspb.2016.0068

Ferrari, M., Lindholm, A. K., König, B. 2019. Fitness Consequences of Female Alternative Reproductive Tactics in House Mice (Mus musculus domesticus). The American Naturalist, 193(1), 106-124. doi: https://doi.org/10.1086/700567

Gaskill, B. N., Pritchett-Corning, K. R., Gordon, C. J., Pajor, E. A., Lucas, J. R., Davis, J. K., Garner, J. P. 2013a. Energy reallocation to breeding performance through improved nest building in laboratory mice. PLoS One, 8(9), e74153. doi: https://doi.org/10.1371/journal.pone.0074153

Gaskill, B. N., Rohr, S. A., Pajor, E. A., Lucas, J. R., Garner, J. P. 2009. Some like it hot: Mouse temperature preferences in laboratory housing. Applied Animal Behaviour Science, 116(2), 279-285. doi:https://doi.org/10.1016/j.applanim.2008.10.002

Gaskill, B. N., Winnicker, C., Garner, J. P., Pritchett-Corning, K. R. 2013b. The naked truth: Breeding performance in nude mice with and without nesting material. Applied Animal Behaviour Science, 143(2), 110-116. doi: https://doi.org/10.1016/j.applanim.2012.10.009

Gerlach, G., Bartmann, S. 2002. Reproductive skew, costs, and benefits of cooperative breeding in female wood mice. Behavioral Ecology, 13(3), 408-418. doi: https://doi.org/10.1093/beheco/13.3.408

Harrison, N., Lindholm, A. K., Dobay, A., Halloran, O., Manser, A., König, B. 2018. Female nursing partner choice in a population of wild house mice (Mus musculus domesticus). Frontiers in Zoology, 15, 4. doi: https://doi.org/10.1186/s12983-018-0251-3

Hayter, A. J., 1989. Pairwise Comparisons of Generally Correlated Means. Journal of the American Statistical Association, 84, 208-213.

Heiderstadt, K. M., Vandenbergh, D. J., Gyekis, J. P., Blizard, D. A. 2014. Communal nesting increases pup growth but has limited effects on adult behavior and neurophysiology in inbred mice. Journal of the American Association for Laboratory Animal Science, 53(2), 152-160.

Inglis, C. A., Campbell, E. R., Auciello, S. L., Sarawar, S. R. 2004. Effects of enrichment devices on stress-related problems in mouse breeding. Animal Welfare Enhancement Reports. Johns Hopkins Center for Alternatives to Animal Testing, pp. 1-9.

Johnson, M. S., Thomson, S. C., Speakman, J. R., 2001. Limits to sustained energy intake. I. Lactation in the laboratory mouse Mus musculus. The journal of Experimental Biology, 204, 1925-1935.

Knight, C. H., Maltz, E., Docherty, A. H. 1986. Milk yield and composition in mice: Effects of litter size and lactation number. Comparative Biochemistry and Physiology Part A: Physiology, 84(1), 127-133. doi: https://doi.org/10.1016/0300-9629(86)90054-X

König, B. 1993. Maternal investment of communally nursing female house mice (Mus musculus domesticus). Behavioural Processes, 30(1), 61-73. doi: https://doi.org/10.1016/0376-6357(93)90012-G

König, B., Markl, H. 1987. Maternal care in house mice. Behavioral Ecology and Sociobiology, 20(1), 1-9. doi: https://doi.org/10.1007/BFoo292161 . 
Leidinger, C. S., Thöne-Reineke, C., Baumgart, N., Baumgart, J. 2018. Environmental enrichment prevents pup mortality in laboratory mice. Lab Animal, 1:23677218777536. doi: https://doi.org/10.1177/0023677218777536

Maestripieri, D., Alleva, E. 1991. Litter defence and parental investment allocation in house mice. Behavioural Processes, 23(3), 223-230. doi:https://doi.org/10.1016/0376-6357(91)90052-2

Manning, C. J., Dewsbury, D. A., Wakeland, E. K., Potts, W. K. 1995. Communal nesting and communal nursing in house mice, Mus musculus domesticus. Animal Behaviour, 50(3), 741-751. doi:https://doi.org/10.1016/0003-3472(95)80134-0

McCullagh, P., Nelder, J. A. 1989. Generalized Linear Models, Second Edition, London: Chapman \& Hall.

Mellor, D. J., Stafford, K. J. 2004. Animal welfare implications of neonatal mortality and morbidity in farm animals. The Veterinary Journal, 168(2), 118-133. doi: https://doi.org/10.1016/j.tvjl.2003.08.004

Mendl, M. 1994. How should parents respond to a reduction in litter size: Abandonment or extra care? Behavioural Processes, 31(2), 285-291. doi: https://doi.org/10.1016/0376-6357(94)90013-2

Poley, W. 1974. Emotionality related to maternal cannibalism in BALB and $\mathrm{C}_{57} \mathrm{BL}$ mice. Animal Learning \& Behavior, 2(4), 241-244. doi: https://doi.org/10.3758/BFo3199187

Reeb-Whitaker, C. K., Paigen, B., Beamer, W. G., Bronson, R. T., Churchill, G. A., Schweitzer, I. B., Myers, D. D. 2001. The impact of reduced frequency of cage changes on the health of mice housed in ventilated cages. Lab Animal, 35(1), 58-73. doi: https://doi.org/10.1258/0023677011911381

Russell, W.M.S., Burch, R.L. 1959 (as reprinted 1992). The principles of humane experimental technique. Wheathampstead (UK): Universities Federation for Animal Welfare.

Satterthwaite, F. E. 1946. An approximate distribution of estimates of variance components, Biometrics Bulletin, 2, 110-114. doi: https://doi.org/10.2307/3002019

Schmidt, J., Kosztolányi, A., Tökölyi, J., Hugyecz, B., Illés, I., Király, R., Barta, Z. 2015. Reproductive asynchrony and infanticide in house mice breeding communally. Animal Behaviour, 101, 201-211. doi:https://doi.org/10.1016/j.anbehav.2014.12.015

The Jackson Laboratory. 2012. Mouse Phenome Database. Accessed 27-1-2015.

Tsai, P. P., Oppermann, D., Stelzer, H. D., Mähler, M., Hackbarth, H. 2003. The effects of different rack systems on the breeding performance of DBA/2 mice. Lab Animal, 37(1), 44-53. doi: https://doi.org/10.1258/002367703762226683

Wasson, K. 2017. Retrospective Analysis of Reproductive Performance of Pair-bred Compared with Trio-bred Mice. Journal of the American Association for Laboratory Animal Science, 56(2), 190-193.

Weber, E. M. 2015. Pup mortality in laboratory mice. Doctoral thesis, Swedish University of Agricultural Sciences. Acta Universitatis agriculturae Sueciae, 1652-6880 ; 2015:6.

Weber, E. M., Algers, B., Hultgren, J., Olsson, I. A. S. 2013a. Pup mortality in laboratory mice infanticide or not? Acta Veterinaria Scandinavica, 55(83). doi: https://doi.org/10.1186/1751-0147-5583

\section{at.}


Weber, E. M., Algers, B., Würbel, H., Hultgren, J., Olsson, I. A. 2013b. Influence of strain and parity on the risk of litter loss in laboratory mice. Reproduction in Domestic Animals, 48(2), 292-296. doi: https://doi.org/10.1111/j.1439-0531.2012.02147.x

Weber, E. M., Hultgren, J., Algers, B., Olsson, I. A. 2016. Do laboratory mouse females that lose their litters behave differently around parturition? PLoS One, 11(8), e0161238. doi: https://doi.org/10.1371/journal.pone.0161238

Weber, E. M., Olsson, I. A. S. 2008. Maternal behaviour in Mus musculus sp.: An ethological review. Applied Animal Behaviour Science, 114(1), 1-22. doi: https://doi.org/10.1016/j.applanim.2008.06.006

Whitaker, J., Moy, S. S., Godfrey, V., Nielsen, J., Bellinger, D., Bradfield, J. 2009. Effects of cage size and enrichment on reproductive performance and behavior in $\mathrm{C}_{57} \mathrm{BL} / 6 \mathrm{Tac}$ mice. Lab Animal, 38(1), 24-34. doi: https://doi.org/10.1038/labano109-24

Whitaker, J., Moy, S. S., Saville, B. R., Godfrey, V., Nielsen, J., Bellinger, D., Bradfield, J. 2007. The effect of cage size on reproductive performance and behavior of $\mathrm{C}_{57} \mathrm{BL} / 6$ mice. Lab Animal , 36(10), 32-39. doi: https://doi.org/10.1038/laban1107-32 
Supplementary data

S1 Dataset https://data.mendeley.com/datasets/mmcrvf3mk8/1

S2 Parturitions with labour complications. Summary of parturitions with labour complications, for single-housed dams $(\mathrm{SH})$ and group-housed dams in trio with $\left(\mathrm{GH}_{1}\right)$ or without $(\mathrm{GHo})$ the presence of another litter.

\begin{tabular}{|c|c|c|c|c|c|}
\hline Parturition problem & Parturition duration & Treatment & Parity & $\begin{array}{l}\text { Litter } \\
\text { size }\end{array}$ & $\begin{array}{l}\text { Litter } \\
\text { loss }\end{array}$ \\
\hline \multirow[t]{6}{*}{ Long-lasting parturition } & $21 h_{32}$ & $\mathrm{GH}_{1}$ & 4 & 3 & yes \\
\hline & 25 hoo & $\mathrm{SH}$ & 4 & 9 & no \\
\hline & 25 ho6 & $\mathrm{GH}_{1}$ & 2 & 10 & no \\
\hline & $25 h_{50}$ & $\mathrm{GH}_{1}$ & 3 & 10 & yes \\
\hline & 28h15 & $\mathrm{GH}_{1}$ & 3 & 10 & no \\
\hline & $30 h_{30}$ & $\mathrm{GH}_{1}$ & 2 & 8 & no \\
\hline \multirow[t]{5}{*}{ Unable to give birth* } & culled & GHo & 3 & 13 & yes \\
\hline & culled & GHo & 3 & 8 & yes \\
\hline & culled & GHo & 5 & 8 & yes \\
\hline & culled & $\mathrm{SH}$ & 4 & 11 & yes \\
\hline & culled & $\mathrm{SH}$ & 3 & 7 & yes \\
\hline
\end{tabular}

*A total of five mice had to be culled more than $24 \mathrm{~h}$ after the start of parturition due to an emaciated and apathetic condition and an inability to give birth to the entire litter. 